\title{
FirSt REPORT OF RHABDIAS (NemATODA: RHABDIASOIDEA) FROM LUNGS OF MONTANE CHAMELEONS IN CAMEROON: DESCRIPTION OF TWO NEW SPECIES AND NOTES ON BIOLOGY
}

\author{
LHERMITTE-VALLARINO N.*, BARBUTO M.**, INEICH I.***, WANJI S.*****, LEBRETON M.*****, \\ CHIRIO L.**** \&AIN O.*
}

\section{Summary:}

The lung nematodes of the genus Rhabdias parasitic in chameleons were previously only known from east Africa and Madagascar. Two new species are described from Cameroon: i) Rhabdias okuensis n. sp., type-host Chamaeleo (Trioceros) quadricornis gracilior, from Mont Oku, is frequent; it resembles R. jarki from Burundi, with a short buccal capsule and a long, thin oesophagus, and is distinguished by its large cervical vesicle and cephalic characters (mouth aperture, papillae). The female parasites are hermaphroditic (spermatozoa identified) and they pierce the lung wall and induce lesions, as $R$. jarki. In the same locality, another chameleon, C. (T.) W. wiedersheimi also harbours R. okuensis, as demonstrated with the 12S rDNA and coxl gene sequences. ii) R. cristati n. sp., type-host C. (T.) cristatus, from Mount Cameroon, is described from one heavily infected specimen; it resembles $R$. chamaeleonis from East Africa, and is distinguished by the large buccal capsule and the thick apex of the intestine. The free-living phase, studied in R. okuensis, presents characters of other Rhabdias from chameleons: heterogony, development of larvae through matricidal endotoky, infective larval stages with a thick, rounded caudal extremity, exuvium transformed into a thick cuticular sheeth. Each free-living female produces one larva, as in other African Rhabdias, whereas the female of R. gemellipara, a parasite of a Malagasy chameleon, produces two larvae.

KEY WORDS : Nematoda, Rhabdiasoidea, Rhabdias okuensis n. sp., Rhabdias cristati n. sp., chameleon, lung, Cameroon.

\section{INTRODUCTION} habdias Stiles \& Hassal, 1905 infecting the lungs of chameleons have until now only been reported from East Africa and for decades, only a

\footnotetext{
* Muséum National d'Histoire Naturelle, USM 307, Département Écologie et Gestion de la Biodiversité \& CNRS IFR 101, 61, rue Buffon, CP52, 75231 Paris cedex 05, France.

** Università degli Studi Milano Bicocca, Dipartimento di Biotecnologie e Bioscienze, Piazza della Scienza 2, 20126 Milano, Italy.

**** Muséum National d'Histoire Naturelle, USM 602, Département de Systématique et Évolution (Reptiles) CP 30, 25, rue Cuvier, 75005 Paris, France.

***** Research Foundation for Tropical Diseases and the Environment, P.O. Box 474, Buea, Cameroon.

****** UCLA/Johns Hopkins Cameroon Programme, CRESAR, BP 7039, Yaoundé, Cameroon.

Correspondence: Odile Bain

Tel.: + 33 (0)1 40793497 - Fax: + 33 (0)1 40793499

E.mail: bain@mnhn.fr
}

Résumé : Présence de Rhabdias (NEMATOda : RhabdiasoideA) DANS LES POUMONS DE CAMÉLÉONS DE MONTAGNE AU CAMEROUN: DESCRIPTION DE DEUX NOUVELLES ESPÈCES ET NOTES SUR LA BIOLOGIE

Les nématodes pulmonaires parasites de caméléons du genre Rhabdias n'étaient connus qu'en Afrique orientale et à Madagascar. Deux espèces sont décrites au Cameroun: i) Rhabdias okuensis n. sp., hôte-type Chamaeleo (Trioceros) quadricornis gracilior au Mont Oku est fréquent; l'espèce est proche de R. jarki, au Burundi, par la capsule buccale courte et l'œsophage long et mince, et en est distincte par la grande vésicule cervicale et des caractères céphaliques (bouche, papilles) Les femelles parasites sont hermaphrodites (spermatozoïdes identifiés); en outre, elles perforent la paroi pulmonaire et provoquent des lésions, comme R. jarki. C. (T.) w. wiedersheimi au Mont Oku héberge aussi R. okuensis, comme celà est démontré par les séquences des gènes $12 \mathrm{~S}$ rADN et coxl. ii) R. cristati $n$. sp., hôte-type C. (T.) cristatus au Mont Cameroun est décrit chez un spécimen fortement parasité: l'espèce est proche de R.

chamaeleonis d'Afrique Orientale, et en est distinct par la grande taille de la capsule buccale et l'apex épais de l'intestin. La phase libre du cycle, étudiée chez R. okuensis, présente les caractères des autres Rhabdias de caméléons: hétérogonie, développement des larves par endotokie matricide, stade infectant avec une extrémité caudale épaisse et arrondie, exuvie transformée en gaine cuticulaire épaisse; chaque femelle libre produit une larve, comme chez les autres Rhabdias africains, alors que la femelle de R. gemellipara, parasite de caméléon malgache, en produit deux.

MOTS CLÉS : Nematoda, Rhabdiasoidea, Rhabdias okuensis n. sp., Rhabdias cristati n. sp., caméléon, poumon, Cameroun.

single species was identified, $R$. chamaeleonis (Skrjabin, 1916) regardless of the host examined (Baylis, 1937; Baker, 1987a), thus strongly contrasting with chameleon diversity (http://www.reptiles-database.org). However a recent morphological analysis of material from Burundi and nearby countries showed divergences among these nematodes (Lhermitte-Vallarino \& Bain, 2004). The hosts of Rhabdias were montane chameleons, i.e. almost exclusively those of the subgenus Trioceros Klaver \& Böhme, 1986, and it was suggested that a humid environment was required for the survival of free-living stages and completion of the lifecycle (Lhermitte-Vallarino \& Bain, 2004).

The present study was performed in west equatorial Africa, in the montane area of Cameroon which is composed of a volcanic chain of isolated mounts (Cameroon Volcanic Line), several of the mounts reaching above 2,000 meters high. This topographically complex 
area is known for its high biodiversity and is considered a biodiversity "hot spot" (Myers et al., 2000). Our study is a part of a larger project in Cameroon to identify the main events that have structured the biodiversity and to provide evidence for explanatory theories such as species refugia, or species pump.

13 chameleon species/subspecies, with six endemic taxa, are recorded in the Cameroon volcanic chain, and they often have distinct, restricted geographical ranges (Gonwouo et al., 2006, 2007). We described the first two new Rhabdias species from west equatorial Africa, from two Trioceros species captured on two distant Cameroun mounts. For one Rhabdias species, specimens were recovered alive; some observations on the parasite life-cycle and host pathology were made; the genetic characterisation (DNA barcode) was established, following the Consortium for the Barcode of Life initiative (CBOL).

\section{MATERIAL AND METHODS}

T The Rhabdias were recovered initially from the reptile collection of the Muséum National d'Histoire Naturelle, Paris (MNHN). These chameleons had been collected by two of us (L.C. \& M.L.) during field studies, between March 2000 and January 2003 (Chirio \& LeBreton, 2007; Gonwouo et al., 2006). In general, chameleons were collected during day time and night time searching by trained herpetologists and field assistants and were preserved in $10 \%$ formalin or ethanol. In selected villages, containers with $10 \%$ formalin were given to field assistants who would preserve any reptiles killed by members of the village in or around their villages and farms; exact location and date of capture are not always available. We used the MNHN collection list to select the chameleons to be dissected. To start, we chose two species of the subgenus Trioceros from two distinct areas in the volcanic chain, Mount Cameroon and Mount Oku. Later, in April-May 2007, a joint field trip was organized with a parasitologist (N. L.-V.) and a herpetologist (I.I.). Dates of capture and environment of chameleons were carefully recorded. Species identification followed the key of Gonwouo et al. (2006) and comparison with other specimens. A tissue sample of each chameleon was taken and fixed in absolute alcohol for molecular analysis. Registration numbers of chameleons registered in the MNHN collection and field numbers are given in square brackets. Details of the geographic distribution, climate and environment of the host species are found in Gonwouo et al. (2006). The Cameroon Ministry of Forests and Fauna authorised the collection and exportation of specimens.

During necropsy of fixed or recently euthanized chameleons, lungs were removed by cutting the trachea posterior to the buccal cavity. Pulmonary lesions were noted. The localisation, number and habitus of Rhabdias females were noted for each lung, as well as presence/absence of first stage larvae and larvated eggs. The digestive tract was also dissected and the nematodes recovered for further taxonomic analysis and evaluation of nematode prevalence and density. Live worms were fixed in $70 \%$ hot alcohol, except those kept for molecular analysis which were individually fixed in absolute alcohol. Coprocultures were made in May 2007; the protocol follows Lhermitte-Vallarino \& Bain (2004).

For the morphological study, fixed specimens were cleared in lactophenol and examined with a Wild microscope equipped with a drawing tube. In some specimens the head was cut with a razor blade and oriented in front view. Measurements are made on drawings, expressed in $\mu \mathrm{m}$, except the body length and distance from vulva to head expressed in millimetres. Several ratios are defined: buccal capsule ratio is length/external diameter; bulb ratio is diameter/body diameter at that level; tail ratio is length/width at level of anus; vulva ratio is the distance head-vulva/body length. Widths at end of oesophagus, midbody and anus are expressed with two numbers; the second in brackets includes the vesicle. Extent of the female genital tract is expressed by two kinds of measures: $i$ ) distance from the bend of anterior tract to head (anterior bendhead) and distance from the bend of posterior tract to tip tail (posterior bend-tip tail); ii) distances from anterior and posterior ovary apices to head. Habitus is expressed by an alphabetical lower case letter. A schematic representation of female anatomy is given for each species, as in previous study (Lhermitte-Vallarino \& Bain, 2004). To determine if the female parasite is hermaphroditic, regions of ovaries producing male gametes and spermaozoa in the oviducts were searched (Schleip, 1911; Goodey, 1924a; Dreyfus, 1937; Lhermitte \& Bain, 2004). Individual dimensions of holotypes, paratypes and other specimens are reported in Tables and range (extremes) in the text. Nematodes are deposited in CollVER MNHN collection.

For the molecular analysis, freshly recovered worms were directly transferred into $100 \%$ ethanol: a female 84 NL from C. (T.) quadricornis gracilior (specimen voucher MIB:zpl:00154); a female 77 NL from C. (T.) w. wiedersheimi (specimen voucher MIB:zpl:00153). Crude DNA preparations were obtained by proteinase$\mathrm{K}$ treatment, according to Bandi et al. (1998). CoxI and $12 \mathrm{~S}$ rDNA amplifications and sequences were obtained following Folmer et al (1994) and Casiraghi et al. (2004). The sequences obtained are about 600 and 500 bp long respectively. PCRs products were gel-purified (using the Perfectprep Gel Cleanup, Eppendorf ${ }^{\mathrm{TM}}$ ) and directly sequenced using $\mathrm{ABI}$ technology. The sequences obtained have been deposited in the EMBL Data 
Library under accession numbers FM179477, FM179479 (12S rDNA and coxI respectively) for specimen voucher MIB:zpl:00153 and FM179476, FM179478 (12S rDNA and coxI respectively) for specimen voucher MIB:zpl: 00154. Sequences were manually aligned and compared using the BioEdit program, version 7.0.1 (Hall, 1999). The alignments generated have been analysed using distance matrix method (i.e. neighbour joining). Phylogenetic analyses were performed using MEGA 4.0 (Tamura et al., 2007).

\section{RESULTS}

T wenty-six chameleons were analyzed for this study and seven harboured lung nematodes. One species of Rhabdias with a very large cervical vesicle was found in the Mount Oku highlands, during 2000-2003 and again in 2007. It was observed in C. (T.) quadricornis gracilior Böhme \& Klaver, 1981, one of both chameleon species recorded in that region (Gonwouo et al., 2006). Worms crossing the lung wall and pulmonary lesions were frequent. The same species of Rhabdias was observed in 2007 in one individual of a second Trioceros species in the same area, C. (T.) w. wiedersheimi Nieden, 1910; while worms were deeply altered, with their large cervical vesicle they appeared similar to those from $C$. (T.) quadricornis gracilior. This was confirmed by the $12 \mathrm{~S}$ rDNA and coxI sequence analysis.

The second species was recovered from C. (T.) cristatus Stutchbury, 1837, captured at Mount Cameroon (CamHerp collections) and not found again in 2007.

\section{RHABDIAS OKUENSIS N. SP. LHERMITTE-VALLARINO \& BAIN (Fig. 1 A-G, 2A-C; Table I)}

Type host: Chamaeleo (Trioceros) quadricornis gracilior Böhme \& Klaver, 1981; adult male captured 19 April 2000 [MNHN 2005-2724].

Type locality: Oku village, 1,973 metres altitude, Mount Oku (6.20N, 10.51E), North West Province, Cameroon. Type material: female holotype $195 \mathrm{CE}$; six female paratypes $195 \mathrm{CE} ; 17$ broken worms in lung tissue.

Other samples from C. (T.) quadricornis gracilior. From Oku village, 19 April 2000, 196 CE [2005-2726]: two anterior and three posterior parts of females, three very young immature females; 197 CE [2005-2727]: one female. 7-8 May 2007, 73 NL [1627 I] and 82 NL [1640 I]: two and one females, respectively. From Oku Lake, 2,272 metres altitude, 8 May 2007, 84 NL [1642 I]: two complete females, two females broken anterior to bulb.

Prevalence: in C. (T.) quadricornis gracilior, Oku village, 3/3, all males, in April 2002; three males/five males, in May 2007.
Other host: C. (T.) w. weidersheimi, 8 May 2007, 77 NL [male $1634 \mathrm{I}$ ]: two female worms. Prevalence: 1/4 in Oku village (two males, two females); 0/2 in Lake Oku and Anyajua-Belo (one female, one male).

Mature gravid females with large body, 15.3 to $19.9 \mathrm{~mm}$ long and 600-760 wide. Habitus: C-shaped bow, bent dorsally, exceptionally S-shaped; constricted region of body posterior to oesophagus in most of the specimens. Cuticle: large anterior vesicle, gradually inflated from head and abruptly interrupted anterior to oesophagus end; maximum thickness 100-160; in one third of the specimens, vesicle with internal transverse striae, distant from each other, sinuous and bifurcated near body; at mid-length of the vesicle, transverse ventral furrow made by the excretory pore extending to worm surface; body vesicle thin or not identified; caudal vesicle present, in general not extended to tip tail. Head: no lips; four papillae distant from mouth aperture and linked with a circular crest; each papilla composed of a salient bright apical point and, more distant from mouth, a large slightly elevated base; two minute amphid openings on slight protuberances, posterior to apex papillae circle. Mouth depressed, subround, lined with thin peribuccal tissue. Buccal cavity short, subround in transverse section, its diameter greater than mouth; buccal capsule, a short and thick cuticularized ring 10-15 long/35-50 external diameter; buccal capsule ratio 0.2-0.3. Oesophagus 1,300-1,500 long, with regular diameter 75-95 from head to bulb; anterior segment distinct with marked muscular fibers; shoulders of oesophagus round, rarely acute; bulb slim, its diameter about $1 / 4$ of body width at that level. Intestine: apex diameter equal to bulb base; a distinct narrow long anterior part, 950-3,000 long. Tail: conical; 380550 long and twice as long as wide at anus; straight or dorsally slightly bent, once ventrally bent; caudal extremity bent or not, gradually attenuated or with a distinct point 50-100 long. Genital tract: coiled oviducts; anterior bend at level of oviducts and far from head, 4,750-6,100; posterior bend 1,000-1,500 from tip tail; vulva ratio $0.56-0.69$.

Immature small adult females (Fig. 3 A-E; Table II): No vesicle. Large and flat buccal capsule with thick wall (buccal ratio $c .0 .2$ ) and thin oesophagus with slim bulb, similar in the large gravid females. Two long excretory cells identified in a specimen. Apex of oesophagus with round shoulders. Width of intestine apex equal to bulb base; no thin cylindrical anterior part. Genital tracts: bends at level of ovaries, near junction with oviducts; vulva ratio 0.58-0.6.

\section{- Taxonomic discussion}

The many species of Rhabdias from amphibians contrast with our material in terms of the short oesophagus (<800 um) (Goodey, 1924b; Travassos, 1926; Yamaguti, 1941; Yuen, 1965; Baker, 1978, 1987b; Kuzmin et al., 


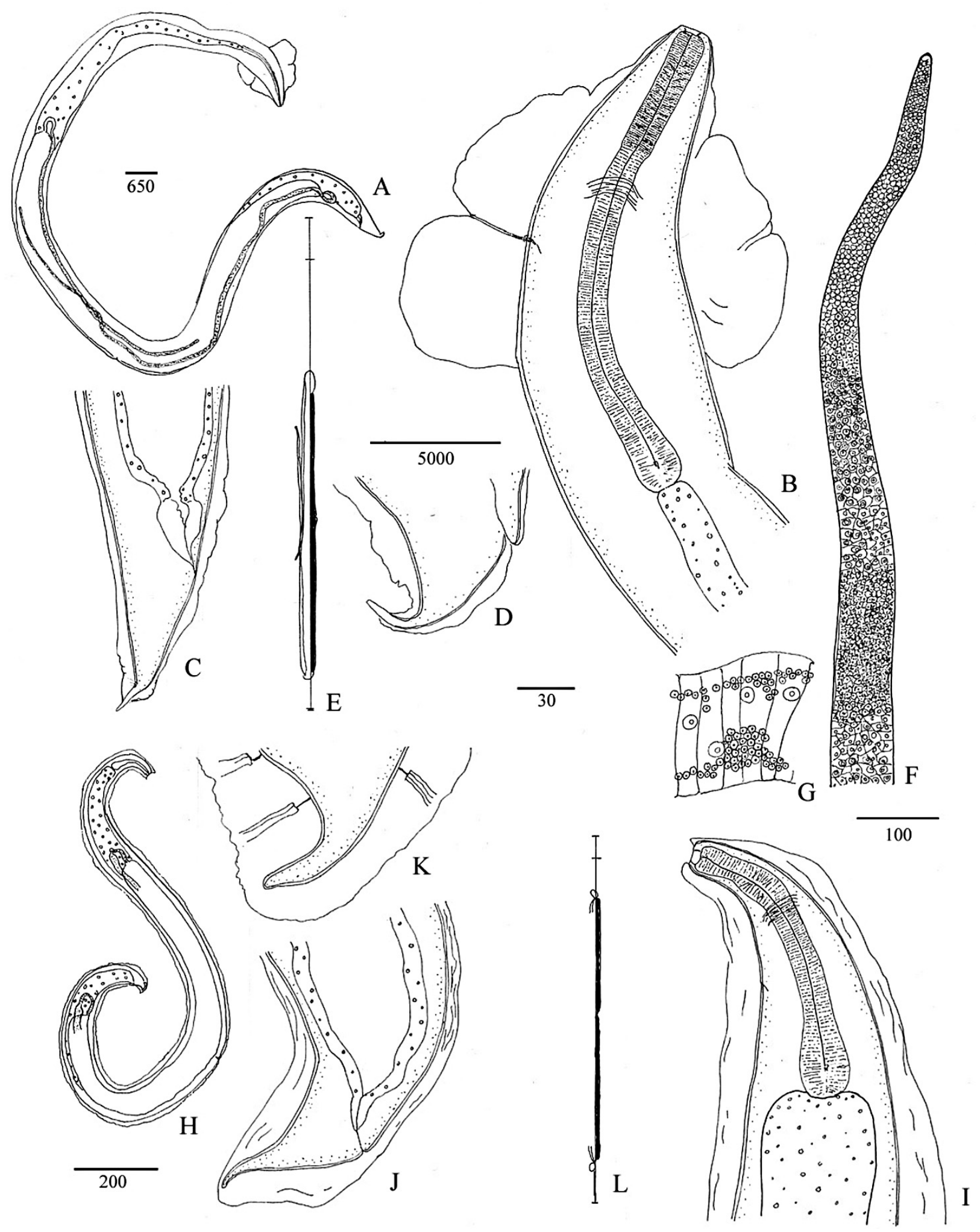

Fig. 1. - Rhabdias spp. A-G. R. okuensis n. sp. A. Habitus, left lateral view, holotype 195 CE 2. B. Anterior region, left lateral view, paratype 195 CE 1. C. Tail of another specimen, right lateral view, paratype 195 CE 5. D. Tail of another specimen, right lateral view 196 CE 5. E. Schematic representation of oesophagus and extent of genital organs in a mature female (holotype); oesophageal-intestinal junction, vulva, uteri (black), oviducts and ovaries are figured. F. Ovary and region producing male gametes. G. Detail of oviduct, its muscle cells and spermatozoa. H-L. R. cristati n. sp. H. Habitus, right lateral view, 186 CE 2D. I. Anterior region, left lateral view, 186 CE 3G. J. Tail, right lateral view, $186 \mathrm{CE}$ 3D. K. Caudal extremity, right lateral view $186 \mathrm{CE}$ 1D, holotype. L. Schematic representation of oesophagus and extent of genital organs in a mature female; paratype $186 \mathrm{CE} \mathrm{1G;} \mathrm{oesophageal-intestinal} \mathrm{junction,} \mathrm{vulva,} \mathrm{uteri} \mathrm{(black),} \mathrm{oviducts} \mathrm{are} \mathrm{figured}$ but not ovaries and their apices which were not identified. Scales in $\mu \mathrm{m}$ : A,H 650; B,C,D,I,J 200; E,L 5,000; F,K 100 ; G 30. 


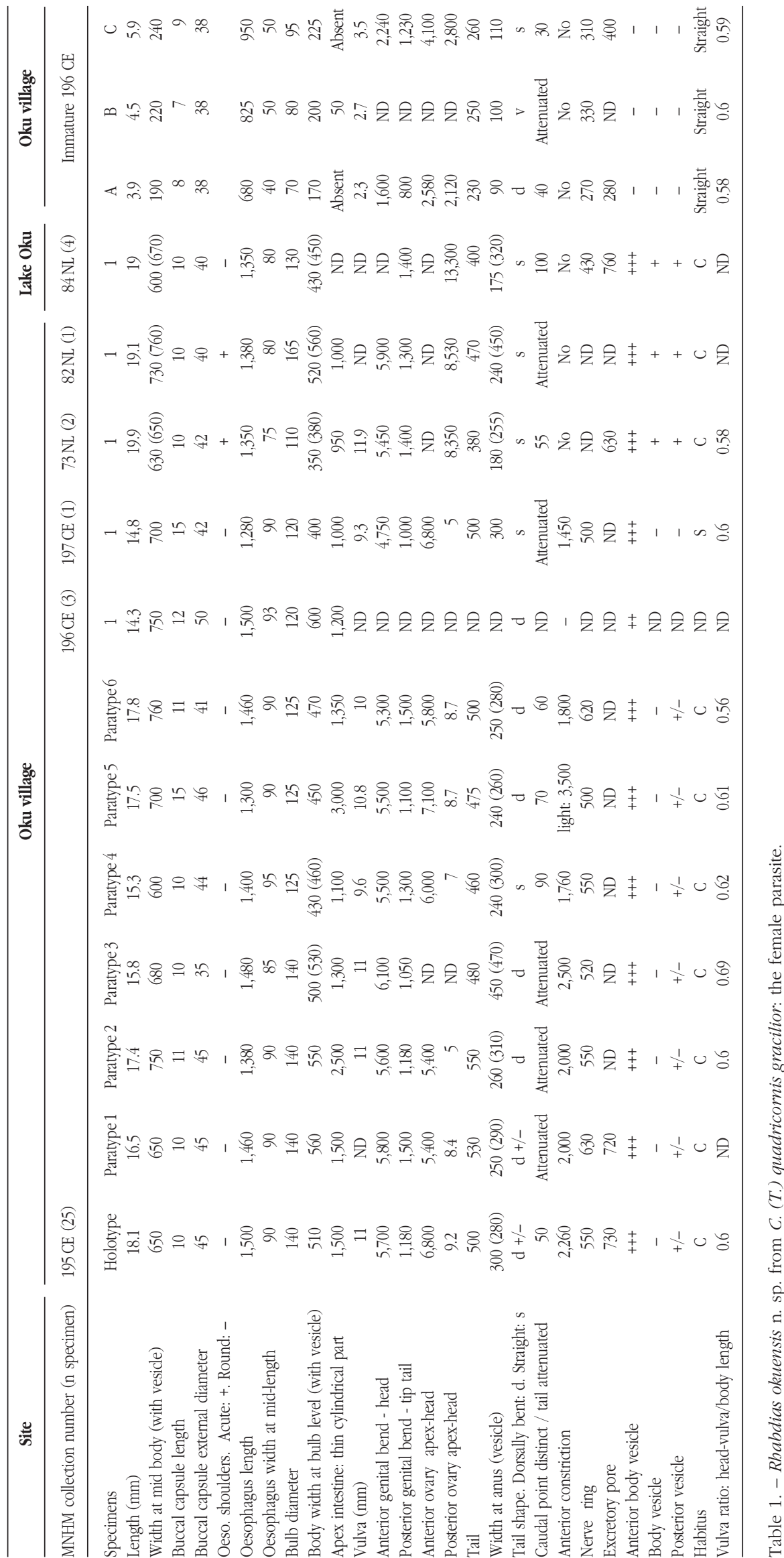


2005, 2007). The few species from ophidians are small, with very short oesophagus and large excretory cells (Goodey, 1924a,b; Lhermitte \& Bain, 2004). The three parasitic species in polychrotid saurians $-R$. anolis Bursey, Goldberg \& Telford, 2003, from Anolis frenatus Cope, 1899 in Panama, R. nicaraguensis Bursey, Goldgerg \& Vitt, 2007 from Norops capito (Peters, 1863) in Nicaragua, and $R$. leonae Martinez-Salazar, 2006 from N. megapholidotus Smith, 1933 in Mexico - are very different from our specimens with the short oesophagus $(\leq 750 \mu \mathrm{m})$, 4-6 lips present and high bulb ratio (0.400.56, after original figures in Bursey et al., 2003, 2007 and Martinez-Salazar, 2006). In addition, $R$. anolis and $R$. nicaraguensis have a short body $(\leq 7.4 \mathrm{~mm})$, a small buccal capsule as long as wide (ratio $=1)$, the excretory pore near end of oesophagus (Bursey et al., 2003, 2007); R. anolis possesses a bulbous anterior swelling on the oesophagus, a relatively elongated tail with two lateral subterminal knobs; $R$. nicaraguensis has a body vesicle with irregular folds and ridges and the tail is constricted behind anus (Bursey et al., 2007). R. leonae exceeds $10 \mathrm{~mm}$ in length like our specimens, but has a cylindrical anterior body part, a cephalic vesicle inflated above the head, a long but narrow buccal capsule (23-34/11-19; ratio 1.78-2), a short tail, equally divided into an anterior thick part and a terminal spike.

The single species described from an agamid, R. japalurae Kuzmin, 2003, type host Japalura polygonata (Hallowell, 1861) from Southern Japan (Okinawa Island), is similar to our specimens with the wide buccal cavity, but it possesses a well-defined vesicle all along the body, dilated at level of oesophageal mid-length, greater buccal capsule ratio (0.57-0.66 vs 0.2-0.3) and bulb ratio (1/3-1/2, from Fig. 1C \& E in Kuzmin, 2003) and shorter oesophagus (921-1037).

The other species of Rhabdias are parasitic in Malagasy and African chameleonids. In Madagascar, one nominal species is recognized at this date, $R$. gemellipara Chabaud, Brygoo \& Petter, 1961. However it is represented by small and "giant" specimens (Chabaud \& Brygoo, 1962; Caballero, 1968) and several species are suspected (Kuzmin, 2003; Lhermitte \& Bain, 2004). This has been confirmed by our current study of the Malagasy small and giant specimens, from the MNHN collection (Lhermitte-Vallarino \& Bain, in preparation). The specimens from Malagasy chameleons all differ from the present material as they have no large anterior vesicle. Moreover, $R$. gemellipara, type host Calumma parsonii (Cuvier, 1824), is distinct with a small body size $(8 \mathrm{~mm})$, small buccal capsule $(8 / 17)$, and short oesophagus (580). The "giant specimens" tentatively assigned to the same species by Chabaud et al. (1962) and Caballero (1968) are not monospecific; distinctive characters from the present material are the followings: species 1 from Ca. cucullatum (Gray, 1831) has a thick oesophagus (135-150 vs 85-100 at mid-length; bulb diameter 210-240 vs $\leq 165$ ); species 2 and 3 from Ca. nasutum (Duméril \& Bibron, 1836) and Ca. brevicornis (Günther, 1879), respectively, have a twice longer buccal capsule (20-32 vs 10-15) and anterior bend of genital tract less distant to head (1,700-2,500 vs 4,750-6,100) (Lhermitte-Vallarino \& Bain, in preparation).

In East Africa, R. chamaeleonis (Skrjabin, 1916), type host undetermined, redescribed by Lhermitte-Vallarino \& Bain, 2004 from C. (T.) jobnstoni (Boulenger, 1901), has a longer buccal capsule $(20-30 \mu \mathrm{m})$ with thin walls, shorter oesophagus $(\leq 1,070 \mu \mathrm{m})$, apex of intestine wider than bulb base and anterior bend of genital tract closer to head (1,800 vs 5,300-6,100). R. jarki LhermitteVallarino \& Bain, 2004, type host C. (T.) johnstoni, is similar to our specimens with the short buccal capsule (13-16) and thick wall, thin and long oesophagus (1,380$1,500)$, bulb ratio small, long narrow anterior part of intestine and anterior bend of the genital tract far from head; but it differs by the absence of expanded anterior vesicle, body shorter $(\leq 12.3 \mathrm{~mm})$ and several cephalic characters: four-lobed mouth aperture, buccal cavity triangular, apex of amphids on the mouth border and salient, and the four papillae reaching mouth border. The specimens described from C. (T.) quadricornis gracilior in Mount Oku belong to a new species that we name $R$. okuensis n. sp.

In the same area, $R$. okuensis $\mathrm{n}$. sp. is also present in C. (T.) $w$. wiedersheimi. This is concluded from the morphological and molecular analyses. The 12S rDNA and the coxI sequences of the specimens from the two chameleon species are identical.

\section{RHABDIAS CRISTATI N. SP. LHERMITTE-VALLARINO \& BAIN (Fig. 1 H-L \& 2 D-F; Table II)}

Type host: Chamaeleo (Trioceros) cristatus Stutchbury, 1837, female adult captured 23 January 2002 [20052968, MNHN].

Type locality: near Etome village, 800 metres, Mount Cameroun (9.11 E, 4.06 N), South West Province, Cameroon.

Type material: female holotype $186 \mathrm{CE}, 15$ females paratypes $186 \mathrm{CE}$, six other females in poor condition, all mature. Specimens deposited in MNHN collection, Paris. Prevalence and intensity: 1/5 from near Etome village; 0/3 from Limbo (Banyang-Mbo), 800 metres; 0/1 from Nyang, 800 metres; 0/7 from Njonji, about 170 metres.

The single infected chameleon had 22 worms, seven and 15 in left and right lungs respectively, all gravid. The morphological study was based on 14 females in good condition. Habitus: variable, bent dorsally; 13 to $15 \mathrm{~mm}$ long and 820-1,000 wide, but two specimens smaller, 7 and $9 \mathrm{~mm}$ long, 520 wide. Cuticular vesicle of body present but fragile and often torn, thicker near extremities; beginning at level of buccal capsule; caudal 

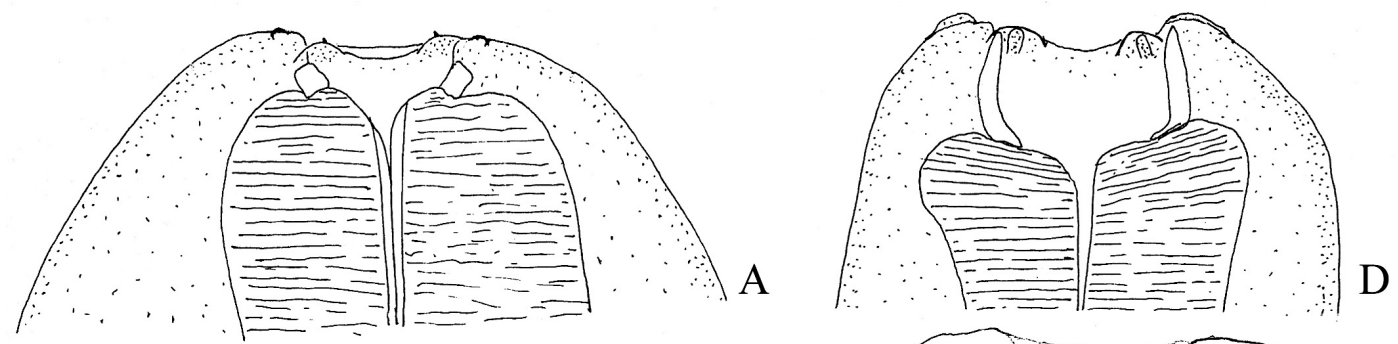

$\mathrm{D}$
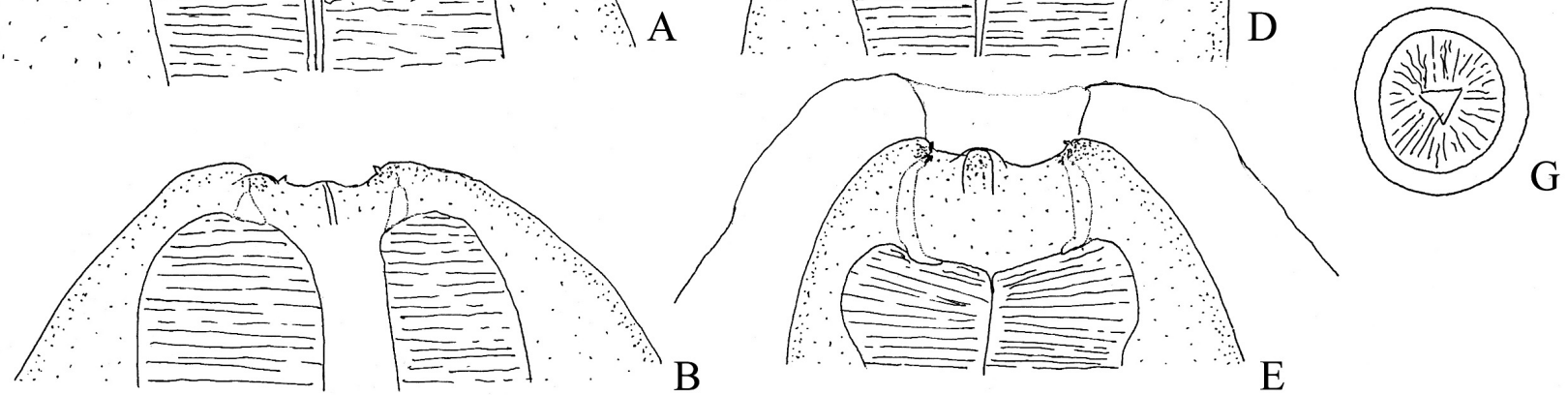

B
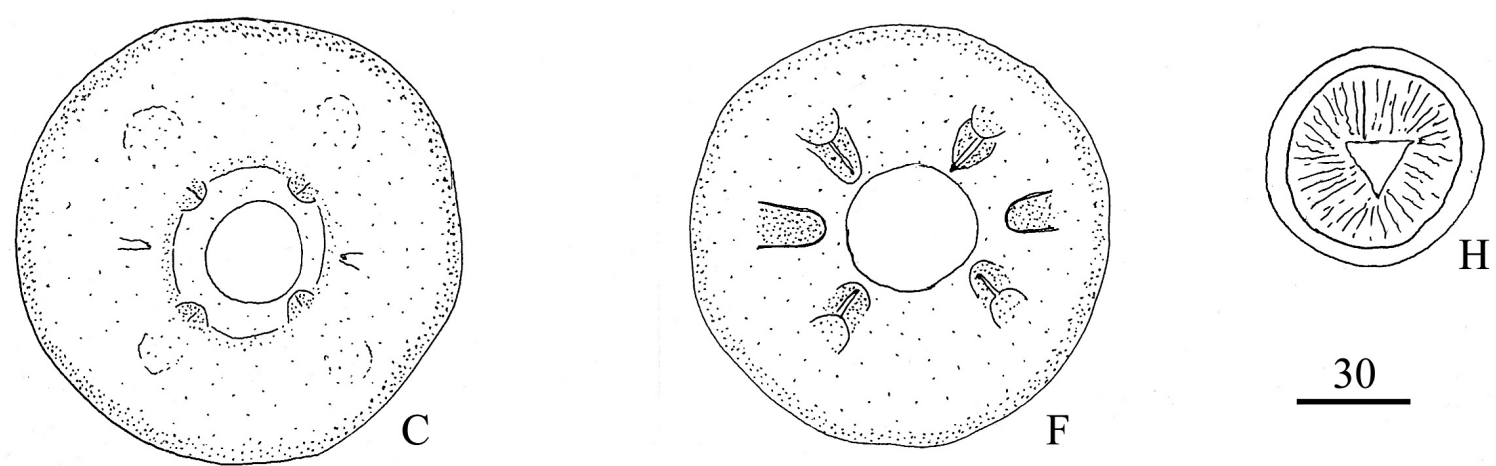

Fig. 2. - Cephalic extremities of Rhabdias spp. A-C. R. okuensis n. sp. Head, median view, lateral view and apical view, respectively, 196 CE 4. D-F. R. cristati n. sp. Head, median view, lateral view and apical view, respectively, 186 CE 4 (cephalic vesicle not drawn, except in E). G \& H. Transverse optical section of buccal capsule of $R$. okuensis and $R$. cristati, respectively. Scale in $\mu$ m: 30.

point inside the vesicle. Head: no lips; four ribbon-like papillae with apex close to mouth, two ribbon-like amphids slightly posterior to papillae. Mouth large, subround, without thin peribuccal tissue (no velum). Buccal cavity large and high, subround in transverse section. Buccal capsule well developed, with wall not very thick, length 30-42, external diameter 50-63. Tiny excretory pore identified in a few specimens $(5 / 16)$. Oesophagus stout; round shoulders; slight inflation just anterior to nerve ring; pear-shaped bulb, its diameter about $1 / 3$ of body width at that level. Intestine: apex flat and twice as wide as bulb diameter, then continuing cylindrically. Tail dorsally curved at level of anus, but straight in the two smaller specimens; anterior part conical, posterior part restricted to form a point with blunt extremity; point straight or bent forward. Genital tract: anterior bend 1,500-2,500 from head, posterior bend 820-1,550 from tip tail; apeces of ovaries not identified due to the very dark intestine. Vulva ratio 0.50 to $0.63 ; 0.47$ in the female $9 \mathrm{~mm}$ long.

- Taxonomic discussion

The three species of Rhabdias which parasitise polychrotid saurians differ from our specimens by the cha- racters listed for $R$. okuensis n. sp. above. R. japalurae is distinct with the small buccal capsule (18-20/28-30) and anterior vesicle swollen at mid-oesophagus length. R. gemellipara Chabaud, Petter \& Brygoo, 1961 differs by its small size. The Malagasy species 1, 2 and 3 ["giant" specimens of $R$. gemellipara sensu Chabaud \& Brygoo, 1962 and Caballero (1968)] differ by their oesophagus longer (1,130-1,500 vs 700-950), buccal capsule less wide (42-48 vs 50-65) and apex of intestine with its diameter equal to bulb diameter. R. jarki and R. okuensis n. sp. differ from the present material by the short buccal capsule and thick wall, long thin oesophagus, the anterior bend of genital tract very far from head and, for $R$. okuensis, the large anterior vesicle. R. chamaeleonis more closely resembles our specimens with the shape of buccal capsule and oesophagus; however it differs by the smaller size of the buccal capsule (2028/30-50 compared to 30-42/50-65), the apex of intestine as wide as bulb base then widening, and cephalic characters: presence of a buccal velum, absence of ribbon-like structure of papillae and amphids.

The specimens described from C. (T.) cristatus in Mount Cameroon are a new species that we name $R$. cristati n. sp. 


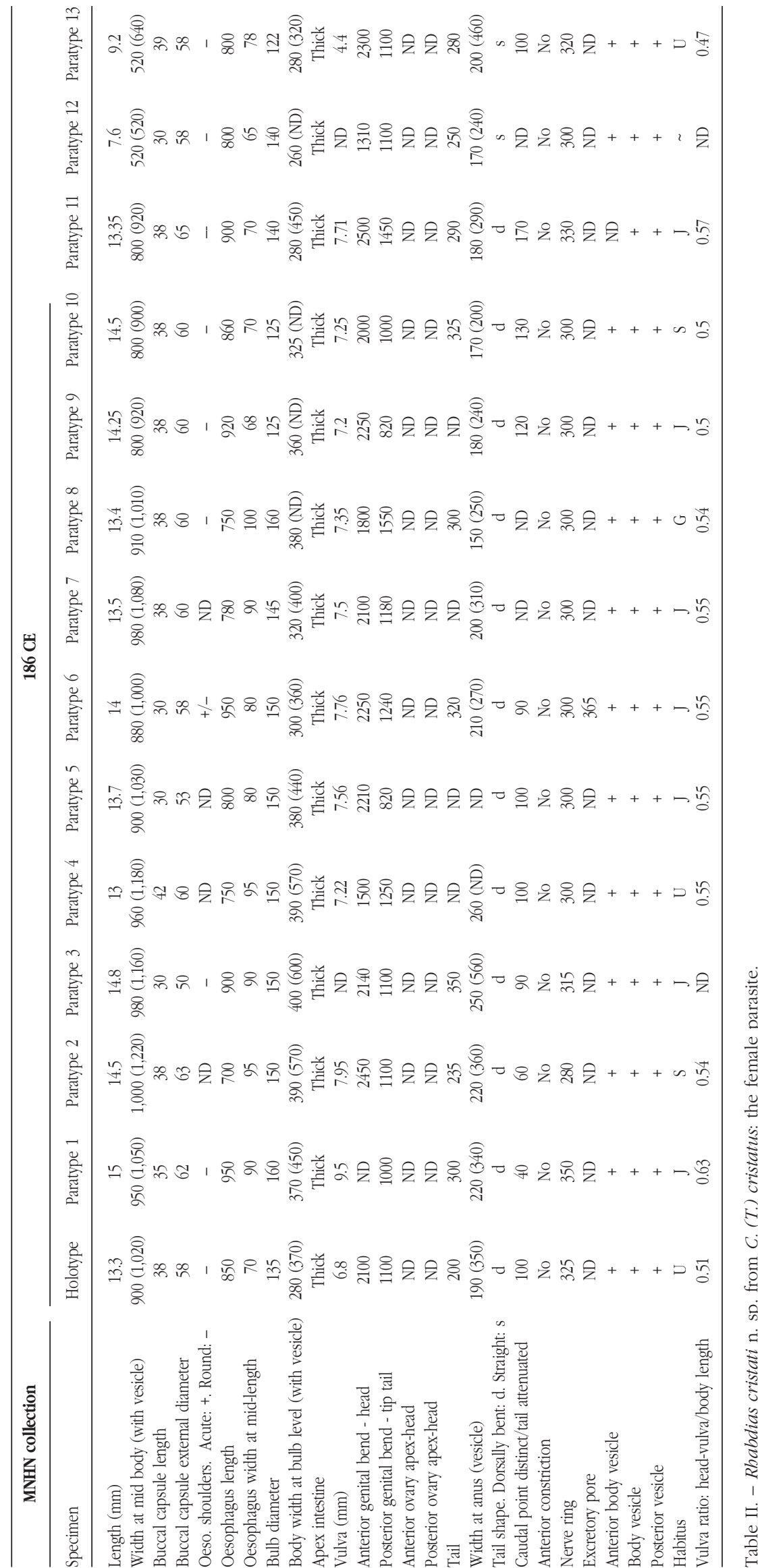


BiOlOgY OF $R$. OKUENSIS N. SP.

(Fig. 1F, G and 3)

The parasitic females of $R$. okuensis were generally crossing the lung wall of $C$. (T.) quadricornis gracilior: the 20 females $195 \mathrm{CE}$, the four mature females $196 \mathrm{CE}$ (not the three young immature worms), the two females $197 \mathrm{CE}$ and the female $82 \mathrm{NL}$. The anterior part of the worm with the large vesicle was extra-pulmonary. These worms were often altered, their vesicle sometimes covered with host cells. In two chameleons, lungs had a fibrotic appearance and one was atrophied. The two young females about $4 \mathrm{~mm}$ long were immature with empty uteri; the female $6 \mathrm{~mm}$ long had 3 altered eggs. In all three, the short ovaries were completely analyzed and no area of male gamete production was identified. Spermatozoa were observed at the end of the two ovaries, near oviducts, in the female $3.9 \mathrm{~mm}$ long (Fig. 3E). A few unusual cells were also identified in this female; they were much smaller than ovulae and larger than spermatozoa; some of them were apparently dividing; these cells were interspersed between ovulae at the end of ovaries; they were hypothesized to be male gametocytes.

Concerning the mature gravid females, a male gamete productive region was observed in one specimen $(84 \mathrm{NL})$, in the anterior ovary; it was 160 long and 650 from ovary apex (Fig. 1F); spermatozoa were identified in the anterior oviduct of the same female (Fig. 1G).

Numerous first stage larvae (L1) were found in the lungs of the infected chameleons collected in 20002003 but not in those euthanased and immediately necropsied in April-May 2007; the presence of L1 in lungs seems a post-mortem artefact. Larvated eggs laid in the lungs pass into the digestive tract, hatch and accumulate in the faeces.

- Free-living stages (Fig. 3 F-L)

First stage larvae developed into adult males and females within three days, at room temperature (coproculture from $82 \mathrm{NL}$ ).

Males $(n=5)$. Body 410-680 long and 30-45 wide; oesophagus 100-160 long; tail 23-50 long; lef and right spicules 20-30 and 25-33 long, gub 13-17. Posterior part bent ventrally. Tail 23-50, as long as wide at level of the cloacal aperture; terminal conical point; short subterminal lateral alae; arrangement of papillae not observed. Spicules subequal, gubernaculum about half the length of spicules. Distance bend of testicle to head equals half to three-quarters the length of oesophagus; this distance bend testicle/head is intermediary between $R$. jarki (very long, ratio 1/1), and R. chamaeleonis (ratio 1/3) (Lhermitte \& Bain, 2004).

Females ( $\mathrm{n}=4$ ). Body 630-920 long and 55-80 width; oesophagus 135-188 long; tail 50-83 long. Tail straight with extremity very attenuated forming a point. One to four eggs; when several eggs are present the one at mid-length is divided and oval in shape. Distance from anterior ovary bend to head longer than oesophagus length; distance from posterior ovary bend to tip tail more than twice the tail length. The extent of female genital tracts and number of eggs resemble those observed in $R$. chamaeleonis (Lhermitte \& Bain, 2004).

Infective stage $(n=1)$. The infective larva was inside the cuticle of the mother. Its morphology was similar to that of $R$. chamaeleonis and $R$. jarki; particularly the tail tip round and decorated with tiny round points; the thick sheath (modified exuviae) was checkered. Maternal body 770 long and 50 wide; larva 630 long, 30 wide, cuticle with longitudinal crests; nerve ring not identified, excretory pore 93 from head, buccal capsule 12 long, oesophagus 155 long with thin bulb; tail 77 long.

\section{DISCUSSION}

T The presence of parasitic Rhabdias in montane chameleons from west equatorial Africa was expected and confirmed in this study perfomed in the volcanic Cameroon chain. The two new species are situated on two distant mounts, Mount Oku in North West Province, and Mount Cameroon in South West Province. The type-host of $R$. okuensis, C. (T.) quadricornis gracilior, is endemic, limited to mountane areas in Cameroon and eastern Nigeria. It is one of two montane species present on Mount Oku. In May 2007, it was captured in the forest remnant patches around the farms of Oku village, although the gallery forest strips are its classic habitat (Gonwouo et al., 2006); these chameleons were all males. In May 2007, individuals of the second species of montane chameleon captured on Mount Oku, C. (T.) w. wiedersheimi, also predominantly males, were captured in cultivated open areas about 1 metre above ground level on small branches, bushes and even grass tussocks. C. (T.) quadricornis gracilior perched higher in the trees. The proximity of the two microhabitats may help explain why $R$. okuensis may infect $C$. (T.) $w$. widersheimi, but with a low prevalence.

R. okuensis is morphologically more similar to R. jarki, from Burundi, than the second species described from Cameroon, $R$. cristati, and conversely, this latter more resembles $R$. chamaeleonis from east Africa. At least two small lineages of Rhabdias seem to have evolved during the divergence of east and west African chameleons to produce two pairs of vicariant species of Rhabdias. Indeed, the hosts species in west equatorial Africa belong to the Chamaeleo cristatus group (Klaver \& Böhme, 1992) and this group is considered to be a sister group of the other east African Trioceros (Townsend \& Larson, 2002). Pathology due to Rhabdias is generally not 

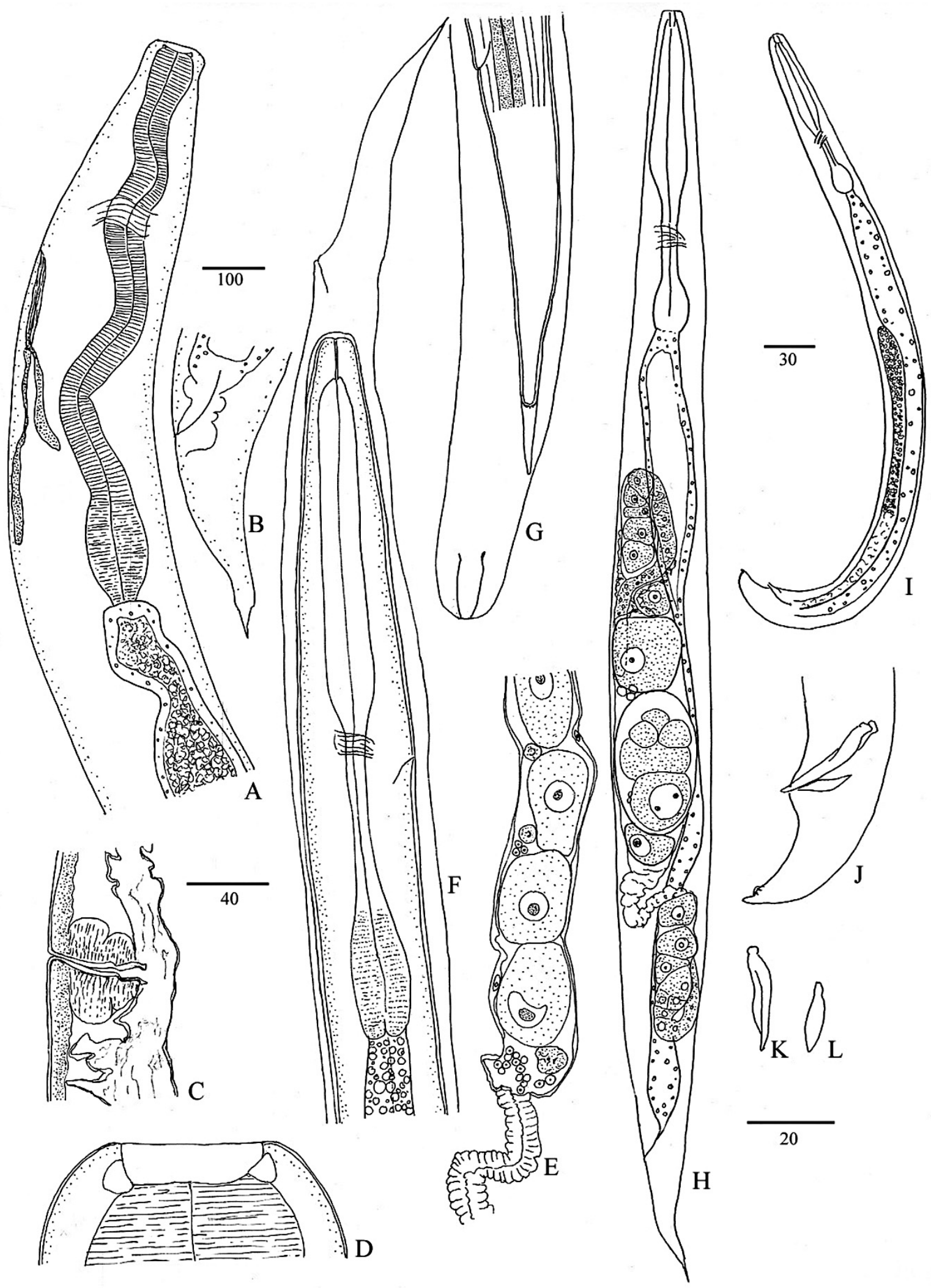

Fig. 3. - Rhabdias okuensis. A-E. Immature female $3.9 \mathrm{~mm}$. A. Anterior region, left lateral view. B. Tail, left lateral view. C. Vulva, vagina and proximal region of empty uteri, left lateral view. D. Buccal capsule, median view. E. Beginning of oviduct and end of ovary with ovulae, spermatozoa and a few small (probably male) dividing cells. F \& G. Infective larva enclosed in a sheeth, within the maternal cuticle (longitudinal crests and lateral chord of the larva drawn in G; checkered ornamentation of the sheeth not drawn). H-L. Heterogonic freeliving adults. H. Female, left lateral view. I. Male, left lateral view. J. Tail, left lateral view; K. A spicule, lateral view. L. Gubernaculum, lateral view. Scales in $\mu \mathrm{m}$ : A,B 100; C,E,F,H 40; D,G,J,K,L 20; I 30. 
reported and it is notable that the two species which induce pulmonary lesions by crossing or digging the lung wall are those morphologically most closely related, $R$. okuensis and $R$. jarki.

The present morphological data confirm our previous remarks on the close relationships between the Rhabdias of the two groups of acrodont lizards, Chamaeleonidae and Agamidae, from the Old World. On the contrary they are distinct from the Rhabdias species of Neotropical polychrotid saurians, which all have a short oesophagus and a narrow buccal capsule.

In this study we analyzed the young specimens in particular to define the characters which change little during the adult stage. This is useful for the identification of immature Rhabdias and to appraise the problem of Malagasy small and giant Rhabdias specimens (Lhermitte-Vallarino \& Bain, in preparation). As underlined by Baker (1978), growth of Rhabdias is allometric. We confirm the conclusions of Lhermitte \& Bain (2004) on the stability of size and shape of the buccal capsule (Tables I \& II) and their diagnostic value. Concerning the oesophagus, when it does not exceed about $900 \mu \mathrm{m}$ in length, it has almost reached that size in the young adults, as it was shown with $R$. chamaeleonis (Lhermitte \& Bain, 2004). If it is longer (1,300$1,500 \mu \mathrm{m}$ ), we observed in this study with $R$. okuensis that there is progressive lengthening during the adult stage (Table I). However the oesophagus shape changes little: the small females of $R$. okuensis have a slim bulb characteristic of the species. In contrast, the cuticular vesicle of the body and shape of intestinal apex are characters which are differentiate during the adult stage. The mode of reproduction of the parasitic female of $R$. okuensis is hermaphrodism, as for $R$. jarki. In the anterior region of the ovary of mature females is a band of small cells which are assumed to generate male gametes (Schleip, 1911; Goodey, 1924a; Dreyfus, 1937; Lhermitte \& Bain, 2004), and spermatozoa are observed in the oviducts. In immature females, spermatozoa accumulate at the end of ovary, not in oviducts, and they seem to be produced by a male cell lineage which is represented by a few cells located in the posterior part of the ovary. In R. cristati, due to the thick black intestine, no observations were made and we cannot conclude that the females are parthenogenetic, as for R. chamaeleonis (Lhermitte-Vallarino \& Bain, 2004), or hermaphroditic.

The newly described cycle for $R$. okuensis is similar to those of other chameleon Rhabdias (Chabaud et al., 1961; Lhermitte-Vallarino \& Bain, 2004): the free living forms are heterogonic; infective larvae develop with matricidal endotoky; and they all possess a round caudal extremity. However, in African Rhabdias, each free-living female produces one infective larva, whereas in Madagascar, that of $R$. gemellipara produces two infective larvae (Chabaud et al., 1961).

\section{ACKNOWLEDGEMENTS}

7 his work was supported by the Agence Nationale de la Recherche ANR Biodoversity project, Iles Forestières Africaines, IFORA, 2006-2009, and by the Partenariat Hubert Curien, Programme Galileo. We thank Ivo Melle Ngwese, our field guide, Laure Pierre in charge of MNHN reptile collection, and Michel Veuille, coordinator of the IFORA project. We also thank the Cameroon Ministry of Forests and Fauna and Ministry of Scientific Research and Innovation for their ongoing support of research efforts in Cameroon.

\section{REFERENCES}

BAKER M.R. Morphology and taxonomy of Rhabdias spp. (Nematoda: Rhabdiasidae) from reptiles and amphibians of southern Ontario. Canadian Journal of Zoology, 1978, 56, 2127-2141.

BAKER M.R. Synopsis of the Nematoda parasitic in amphibians and reptiles. Memorial University of Newfoundland, Canada. Occasional papers in Biology, Ed. Gordon F. Bennett, 1987a, 11, $325 \mathrm{p}$.

BAKer M.R. Rhabdias collaris n. sp. (Nematoda: Rhabdiasidae) form frogs of Tanzania. Systematic Parasitology, 1987b, 9, 199-201.

Bandi C., Anderson T.J.C., Genchi C. \& Blaxter M.L. Phylogeny of Wolbachia in filarial nematodes. Proceedings of the Royal Society of London, 1998, B, 265, 2407-2413.

BAylis H.A. Some parasitic worms from East African chameleons. Annals and Magazine of Natural History, 1937, series 10, 19, 584-593.

Bursey C.R., Goldberg S.R. \& TelFord S.R. Rhabdias anolis n. sp. (Nematoda: Rhabdiasidae) from the lizard, Anolis frenatus (Sauria: Polychrotidae), from Panama. Journal of Parasitology, 2003, 89, 113-117.

Bursey C.R., Goldberg S.R. \& VitT L.J. New species of Rhabdias (Nematoda: Rhabdiasidae) and other helminths from Norops capito (Sauria: Polychrotidae) from Nicaragua. Journal of Parasitology, 2007, 93, 129-131.

CABallero G. Contribution à la connaissance des nématodes de sauriens malgaches. Annales de Parasitologie Humaine et Comparée, 1968, 43, 149-200, 353-380.

Casiraghi M., Bain O., Guerrero R., Martin C., Pocacqua V, Gardner S.L., Franceschi A. \& Bandi C. Mapping the presence of Wolbachia pipientis on the phylogeny of filarial nematodes: evidence for symbiont loss during evolution. International Journal of Parasitology, 2004, 34, 191-203.

Chabaud A.G. \& Brygoo E. Nématodes parasites de caméléons malgaches. Deuxième note. Annales de Parasitologie Humaine et Comparée, 1962, 37, 125-159.

Chabaud A.G., Brygoo E.R. \& PetTer A. Description et caractères biologiques de deux nouveaux Rhabdias malgaches. Annales de Parasitologie Humaine et Comparée, 1961, 36, 752-763.

Chirio L. \& Lebreton M. Atlas des reptiles du Cameroun. In: Collection Patrimoines Naturels, Publications IRD/MNHN, 2007, 67, 686 p. 
Dreyfus A. Contribuiçào para o estudo do cyclo chromosomico e da determinaçào do sexo de Rhabdias fuelleborni Trav. 1926. Boletins da Faculdade de Philosophia, Sciencias e Letras, Universidade de Sào Paulo, 1937, Biologia General n 1 , $144 \mathrm{p}$.

Folmer O., Black M., Hoeh W., LutZ R. \& VRijenhoek R. DNA primers for amplification of mitochondrial cytochrome $\mathrm{C}$ oxidase subunit I from diverse metazoan invertebrates. Molecular Marine Biology and Biotechnology, 1994, 3, 294297.

Gonwouo L.N., Lebreton M., Wild C., Chirio L., Ngassam P. \& Tснамва M.N. Geographic and ecological distribution of the endemic montane chameleons along the Cameroon mountain rahge. Salamandra, 2006, 42, 213-230.

Gonwouo L.N., Lebreton M., Chirio L., Ineich I., Tchamba M.N., Ngassam P., Dzikouk G. \& Diffo J.L. Biodiversity and conservation of the reptile of the Mount Camerooon area. African Journal of Herpetology, 2007, 56, 149-161.

GoOdey T. The anatomy and life-history of the nematode Rhabdias fuscovenosa (Railliet) from the grass snake Tropidonotus natrix. Journal of Helminthology, 1924a, 2, 51-64.

GoOdey T. Two new species of the nematode genus Rhabdias. Journal of Helminthology, 1924b, 2, 203-208.

Hall T.A. BioEdit: a user-friendly biological sequence alignment editor and analysis program for Windows 95/98/NT. Nucleic Acids Symposium Series, 1999, 41, 95-98.

Klaver C. \& Böhme W. Phylogeny and classification of the Chamaeleonidae (Sauria) with special reference to hemipenis morphology. Bonner Zoologische Monographien, 1986, 22, 1-64.

Klaver C. \& Böhme W. The species of the Chamaeleo cristatus group from Cameroon and adjacent countries, West Africa. Bonner Zoologische Beiträge, 1992, 43, 433-476.

Kuzmin Y. Rhabdias japalurae sp. nov. (Nematoda, Rhabdiasidae) from the japalures (Reptilia, Agamidae) and some notes on other Rhabdias spp. from lizards. Acta Parasitologica, 2003, 48, 6-11.

Kuzmin Y., TKach V.V. \& Brooks D.R. Two new species of Rhabdias (Nematoda, Rhabdiasidae) from the marine toad, Bufo marinus (L.) (Lissamphibia: Anura: Bufonidae), in Central America. Journal of Parasitology, 2007, 93, 159165.

Kuzmin Y., TKach V.V. \& Vaughan J.A. Rhabdias kongmongthaensis sp. n. (Nematoda, Rhabdiasidae) from Polypedates leucomystax (Amphibia: Anura: Rhacophoridae) in Thailand. Folia Parasitologica, 2005, 52, 339-342.

LHERMITTE-VALLARINO N \& BAIN O. Morphological and biological study of Rhabdias spp. (Nematoda) from African chameleons with description of a new species. Parasite, 2004, $11,15-31$

Martinez-Salazar E.A. A new rhabdiasid species from Norops megapholidotus (Sauria: Polychrotidae) from Mexico. Journal of Parasitology, 2006, 92, 1325-1329.

Myers N., Mittermeier R.A., Mittermeier C.G, Da Fonseca G.A.B. \& KENT J. Biodiversity hotspots for conservation priorities. Nature, 2000, 403, 853-858.

SCHLEIP W. Das Verhalten des Chromatins bei Angiostomum (Rhabdonema) nigrovenosum. Ein Beitrag zur Kenntis der
Beziehungen zwischen Chromatin und Geschlechtsbestimmung. Archiv für Zellforschung, Leipzig, 1911, 7, 87-138.

SkRJABIN K.I. Parasitic trematodes and nematodes collected by the expedition of Prof. V. Dogiel and I. Sokolov in British East Africa. In: Scientific Results of the Zoological Expedition to British East Africa and Uganda made by Prof. V. Dogiel and I. Sokolov in the year 1914, 1916, 1, 99-157.

Tamura K., Dudley J., Nei M. \& Kumar S. MEGA 4: Molecular evolutionary Genetics Analysis (MEGA) software version 4.0. Molecular Biology and Evolution, 2007, 24, 15961599.

TOWNSEND T. \& LARSON A. Molecular phylogenetics and mitochondrial genomic evolution in the Chamaeleonidae (Reptilia: Squamata). Molecular Phylogenetics Evolution, 2002, 23, 22-36.

Travassos L. Entwicklung des Rhabdias fülleborni n. sp. Archiv für Schiffs - und Tropen-Hygiene, 1926, 30, 594-602.

YAMAGUTI S. Studies of the helminth fauna of Japan. Pt 34. Amphibian nematodes, II. Japanese Journal of Zoology, 1941, 9, 397-408.

YUEN P.H. Some studies on the taxonomy and development of some Rhabdiasoid and Cosmocercoid nematodes from Malayan amphibians. Zoologischer Anzeiger, 1965, 174, 275-298.

Reçu le 10 juillet 2008 Accepté le 29 août 2008 